\section{The Effect of Fertilization and Irrigation on Maize (Zea mays L.) Production}

\author{
Attila Megyes - Tamás Rátonyi - László Huzsvai \\ University of Debrecen, Centre for Agricultural Sciences, \\ Faculty of Agricultural Sciences, \\ Department of Land Use and Rural Development, Debrecen
}

\section{SUMMARY}

In a long-term field experiment set up at the Látókép experimental station of the Center of Agricultural Sciences of Debrecen University, the data of the last five years (1995-1999) were analyzed to determine the crop production factors with the greatest influence on maize production and the relationship and interactions between irrigation and fertilization.

In the extremely dry year of 1995, fertilization was found to cause substantial yield depression in the absence of irrigation. According to results of analysis of variance, fertilization significantly reduced the maize yield by 40-90\% compared to control plots. Under irrigated conditions, there was a considerable increase in the maize yield, the yield surplus being 4.4-9.4 t ha-1, depending on the nutrient supply level.

During the period from 1996-1999, when rainfall conditions were favorable for maize, fertilization significantly increased the maize yield even without irrigation over the average of the four years. The yield surplus due to fertilization was 3.9-4.6 t ha-1, depending on the fertilization rates. The maximum yield surplus was obtained on plots fertilized with $120 \mathrm{~N} \mathrm{~kg} \mathrm{ha-1,} \mathrm{while} \mathrm{at} \mathrm{the}$ rate of $240 \mathrm{~N} \mathrm{~kg} \mathrm{ha-1} \mathrm{the} \mathrm{maize} \mathrm{yield} \mathrm{did} \mathrm{not} \mathrm{differ} \mathrm{significantly}$ from this value. During the period examined, corn yield was significantly higher at all three nutrient supply levels as the result of irrigation than in the non-irrigated treatment. As in the case of non-irrigated conditions, the highest fertilizer dose did not result in a substantial yield increase. An analysis of the interaction between fertilization and irrigation indicated that the yieldincreasing effect of fertilization was not significantly different under irrigated and non-irrigated conditions. The significant year $x$ irrigation interaction was confirmed by the fact that the yield surplus (1.3-2.3 $t$ ha-1) differed greatly from the irrigation effect recorded in 1995.

\section{INTRODUCTION}

Both Hungarian and foreign scientific publications agree that, of the factors influencing fertilizer effect, weather, soil characteristics, water supply, uniformity of plant stock, the cultivated plant and the fertilizer reaction of the strain are the most decisive. Weather, since it regulates the heat and moisture supply of the growing site, has an effect on the transformation of materials, the growth of plants, nutrient uptake and thus on the influence of fertilizers (Kramer, 1963; Kovács, 1982; Nagy, 1996). The amount of precipitation or the moisture stored in the soil modifies the need for manure as well as the effect of fertilization. The effect of fertilization increases with optimal water supply and decreases when harmful water excess is reached (Nagy, 1994, 2000, 2001). The irrigation and fertilization experiment results of Nagy $(1995,1997)$ have proved, that irrigation increases the efficiency of fertilization and that there is a strong correlation between fertilizer utilization and the water supply of plants. In irrigated treatment, which means a higher yield level, due to the positive correlation between irrigation $\mathrm{x}$ fertilization, the economic fertilizer doses are greater than without irrigation. In irrigated cultivation, the effect of year is moderate and yield fluctuation decreases.

Results of experiments have proved that irrigation in general increases the yield of maize and especially in cases of drought. If precipitation and the easily accessible water supply of the soil do not satisfy the needs of the plant, then the deficiency has to be compensated with irrigation (Petrasovits, 1978). Irrigation will be increasingly important in certain parts of the country to ensure intensive production of maize (Szőke Molnár, 1977). Especially the period from the second half of the 1980's until the mid 1990 's, which was extremely droughty, put irrigation in the center of attention. Accurate irrigation forecast can only be given if there is knowledge about precipitation and soil moisture conditions regarding the plot (Balogh, 1978).

\section{MATERIALS AND METHODS}

The conditions of the experiment. We examined the correlation and existing relationships among the factors that are of great significance, especially between irrigation and fertilization, on the basis of evaluating the data of the past 5 years $(1995,1996-$ 1999) of experiments carried out at Látókép of the Center for Agricultural Sciences, Debrecen University. The location of the examinations was the multi-factorial long-term experiment set up at the Experimental Station of Látókép, on mid-bound chernozem soil with lime deposits. The long-term experiment was in split-split-plot set up, the soil cultivation and irrigation variants were in the main plot without repetitions. On the primary subplots, the maize hybrids were set up in 30-50-70-90 thousandplant densities, while on the secondary sub-plots the fertilizer treatment was in four repetitions in random order. One soil cultivation block takes up $8756 \mathrm{~m}^{2}$, which is divided into an irrigated and unirrigated block. The plot of the fertilizer treatments is $2918 \mathrm{~m}^{2}$, in four repetitions. The examined hybrid was the Dekalb 471 SC hybrid. In our experiments, we had winter tillage $(27 \mathrm{~cm})$ cultivation method. The examinations were carried out on unfertilized (control) plots with $\mathrm{N}_{120} \mathrm{P}_{90} \mathrm{~K}_{108} \quad \mathrm{~kg}$ ha-1 and $\mathrm{N}_{240} \mathrm{P}_{180} \mathrm{~K}_{216} \mathrm{~kg}$ ha-1 doses, with 70000 ha-1 plant density, in unirrigated and irrigated treatments. The total amount of fertilizer was applied in the fall, 
without any division. During irrigation, an amount close to the water needs of the maize stock was applied. Our research on this topic was supported by the Hungarian Scientific Research Fund (T029276, T31989).

Soil characteristics: The soil of the Experimental Station is lowland chernozem with lime deposits. The $\mathrm{N}$ - and P-supply of the soil is medium, its K- content is high (humus content $=2.8-3.0 \%$, Total $\mathrm{N}=0.14$ $0.18 \%$; AL- $\mathrm{P}_{2} \mathrm{O}_{5}=130-200 \mathrm{mg} \mathrm{kg}-1, \mathrm{AL}-\mathrm{K}_{2} \mathrm{O}=$ 240-280 mg kg-1). The thickness of the humus layer is $70-90 \mathrm{~cm}$. The $\mathrm{pHKCl}$ value is 6.2 ; the coefficient suggested by Arany is 43. Microelement deficiency cannot be detected. The ground water level is between $6-8 \mathrm{~m}$. The VKmin value of the soil is 27-29 $\mathrm{tf} \%$. The $0-100 \mathrm{~cm}$ soil layer is able to withhold 275 $\mathrm{mm}$, while the $100-200 \mathrm{~cm}$ can store $265 \mathrm{~mm}$ of moisture. The useful water capacity in the $0-100 \mathrm{~cm}$ soil layer is $157 \mathrm{~mm}$, in the $100-200 \mathrm{~cm}$ layer it is $150 \mathrm{~mm}$.

Weather characteristics: In 1995, $114 \mathrm{~mm}$ fell during the growing season while in the winter season, $23 \mathrm{~mm}$ less precipitation fell than compared to the fifty-year average. Only $3 \mathrm{~mm}$ of rain fell in July. The period in July and August during flowering and grain filling, lasting 50 days without rain and was paired with a maximum $30^{\circ} \mathrm{C}$ temperature, unfavorably affected yield results. Due to the effect of 1995 and the previous droughty years, yield depression occurred in the fertilized, unirrigated treatments. The weather of the period between 1996 and 1999 was significantly favorable for maize. Both in the winter term and in the vegetative period sufficient precipitation fell. The distribution as well as the amount of precipitation was favorable, especially in the period of July and August, which is so critical for the development maize plants. Contrary to the year of 1995, in 1998 and 1999 the flood-like rain, which well exceeded the average of many years, caused problems.
Statistical evaluation. Our research program was designed with up-to-date experiment planning, to achieve a reliable evaluation, using the further developed version of the Box and Wilson (1951) method. The evaluation of the experimental data was done with variance analysis, by breaking down the variance components (Sváb, 1981; Drimba and Ertsey, 2003; Drimba et al., 2000; Ertsey and Drimba, 1995). We have used the 9.0 version of the SPSS for Windows to evaluate the data.

\section{RESULTS AND DISCUSSION}

We examined the effect of fertilization in irrigated and unirrigated treatments, at three fertilizer levels, in four repetitions by using the yield data of five years set up at the experimental station at Látókép. The evaluation of experimental results were done with variance analysis. The period between 1996-1999, that covers the wet years, was evaluated in the average of four years and we have compared the dry and droughty data of 1995 .

According to our examinations, irrigation and fertilization has shown a strong correlation with yield results. The effect of irrigation changed depending on the natural water supply and nutrient supply of soil, and the specific fertilizer doses. On the basis of analysis results, we have found that both fertilization and the effect of irrigation were significant on yield results. The correlation of year and examined cultivation technology elements or factors were also reliable. In the average of years, the yield increasing effect of fertilization differed reliably in irrigated treatments. When examining the years separately, the correlation between the two factors was not significant in the period from 1996-1999, which had more precipitation. The results of examinations are shown in Table 1.

Results of analysis of variance

(Debrecen, 1995, 1996-1999)

\begin{tabular}{|l|r|r|r|r|r|}
\hline \multicolumn{1}{|c|}{ Source of variance } & \multicolumn{1}{c|}{ SS } & \multicolumn{1}{c|}{ df } & \multicolumn{1}{c|}{ MS } & \multicolumn{1}{c|}{ F } & \multicolumn{1}{c|}{$\boldsymbol{\alpha}$-error } \\
\hline Year & 500.93 & 1 & 500.93 & 328.93 & $\approx 0.0000$ \\
\hline Irrigation & 372.50 & 1 & 372.50 & 44.60 & $\approx 0.0000$ \\
\hline Fertilization & 81.20 & 2 & 40.60 & 26.66 & $\approx 0.0000$ \\
\hline Year x Fertilization & 131.02 & 2 & 65.51 & 43.01 & $\approx 0.0000$ \\
\hline Irrigation x Fertilization & 24.64 & 2 & 12.32 & 8.09 & $\approx 0.0005$ \\
\hline Error & 164.47 & 108 & 1.52 & & \\
\hline Total & 1420.21 & 118 & & & \\
\hline
\end{tabular}

In the especially dry, droughty year of 1995 , when evaluating the effect of fertilization, we have found that without irrigation the fertilizer doses cause yield depression. According to the results of variance analysis, fertilization significantly decreased the yield of maize. In the fertilized treatments, compared to the results of control plots, yield was 40-90\% lower depending on the level of fertilization. The negative fertilizer effect was the consequence of lasting water deficiency which occured during flowering, as well as the significantly high daily temperature exceeding $30^{\circ} \mathrm{C}$. Due to the effect of medium and high doses of fertilization, in the begining of the growing season, a significant assimilation surface developed, increasing the risk of excessive evaporation. In the second half of the vegetative period - which overlapped the significantly droughty period - the high LAI, as well as due to the increased water need maize was in a 
state of severe water deficiency, the considerable yield decrease occured as a result of this.

In 1995, the yield of maize increased significantly in irrigated conditions, the surplus yield reached around 4.4-9.4 $\mathrm{t} / \mathrm{ha}$ depending on the level of nutrient supply. The greatest irrigation effect was achieved on the fertilized plot of $120 \mathrm{~kg}$ ha-1 nitrogen active substance, however when applying $240 \mathrm{~kg}$ ha-1 Ndose, the efficiency of irrigation was very low and yield was lower, compared to the results of $120 \mathrm{~kg}$ ha-1 N-dose about 3 tons less, practically identical with the output of unfertilized control plots (Table 2). It is clear from the data that the yield of maize in
1995 on the fertilized plots did not reach the measured averages of the unirrigated, fertilized treatments of the 1996-1999 period. Comparing the control, unfertilized plots of the two periods, the yield of maize was reliably higher by $1.3 \mathrm{t} / \mathrm{ha}$ than that of the unirrigated 1996-1999 period which was high in precipitation (Figure 1). All this implies that the cumulated droughty years of the 1990's, the period between 1992-1995, due to the negative water balance evolved during the growing season, water supply stored in the soil was relatively low compared to the control plots with fertilized treatments and natural nutrient supply.

Effect of fertilization and irrigation on yield of maize

Table 2 (Debrecen, 1995, 1996-1999)

\begin{tabular}{|c|c|c|c|c|c|c|c|}
\hline \multirow{2}{*}{\multicolumn{2}{|c|}{ Fertilizer rates }} & \multicolumn{6}{|c|}{ Non-irrigated } \\
\hline & & 1995 & 1996 & 1997 & 1998 & 1999 & $\begin{array}{c}\text { Average } \\
(1996-1999)\end{array}$ \\
\hline \multicolumn{2}{|c|}{$\mathrm{N}_{0} \mathrm{P}_{0} \mathrm{~K}_{0} \mathrm{~kg}$ ha- 1} & 3.83 & 7.85 & 5.54 & 6.44 & 8.02 & 6.96 \\
\hline \multicolumn{2}{|c|}{$\mathrm{N}_{120} \mathrm{P}_{90} \mathrm{~K}_{108}$ kg ha- 1} & 1.60 & 10.23 & 11.82 & 11.74 & 12.60 & 11.60 \\
\hline \multicolumn{2}{|c|}{$\mathrm{N}_{240} \mathrm{P}_{180} \mathrm{~K}_{216} \mathrm{~kg}$ ha- 1} & 0.42 & 8.75 & 11.21 & 11.50 & 12.01 & 10.87 \\
\hline \multicolumn{2}{|c|}{ Average } & 1.95 & 8.94 & 9.52 & 9.89 & 10.88 & 9.81 \\
\hline & & \multicolumn{6}{|c|}{ Irrigated } \\
\hline \multicolumn{2}{|c|}{$\mathrm{N}_{0} \mathrm{P}_{0} \mathrm{~K}_{0} \mathrm{~kg}$ ha- 1} & 8.26 & 9.78 & 6.18 & 8.24 & 8.65 & 8.21 \\
\hline \multicolumn{2}{|c|}{$\mathrm{N}_{120} \mathrm{P}_{90} \mathrm{~K}_{108}$ kg ha- 1} & 11.02 & 11.84 & 13.23 & 14.15 & 13.30 & 13.13 \\
\hline \multicolumn{2}{|c|}{$\mathrm{N}_{240} \mathrm{P}_{180} \mathrm{~K}_{216} \mathrm{~kg}$ ha- 1} & 8.04 & 13.21 & 12.49 & 13.08 & 13.38 & 13.04 \\
\hline \multicolumn{2}{|c|}{ Average } & 9.11 & 11.61 & 10.63 & 11.82 & 11.78 & 11.46 \\
\hline & Irrigation & 0.39 & & & & & 0.44 \\
\hline \multirow[t]{2}{*}{ LSD5\% } & Fertilization & 0.51 & & & & & 0.55 \\
\hline & Irrig. $\mathrm{x}$ Fert. & 0.86 & & & & & Non-significant \\
\hline
\end{tabular}

Figure 1: Effect of fertilization on maize yield under irrigated and non-irrigated conditions (Debrecen, 1995, 1996-1999)

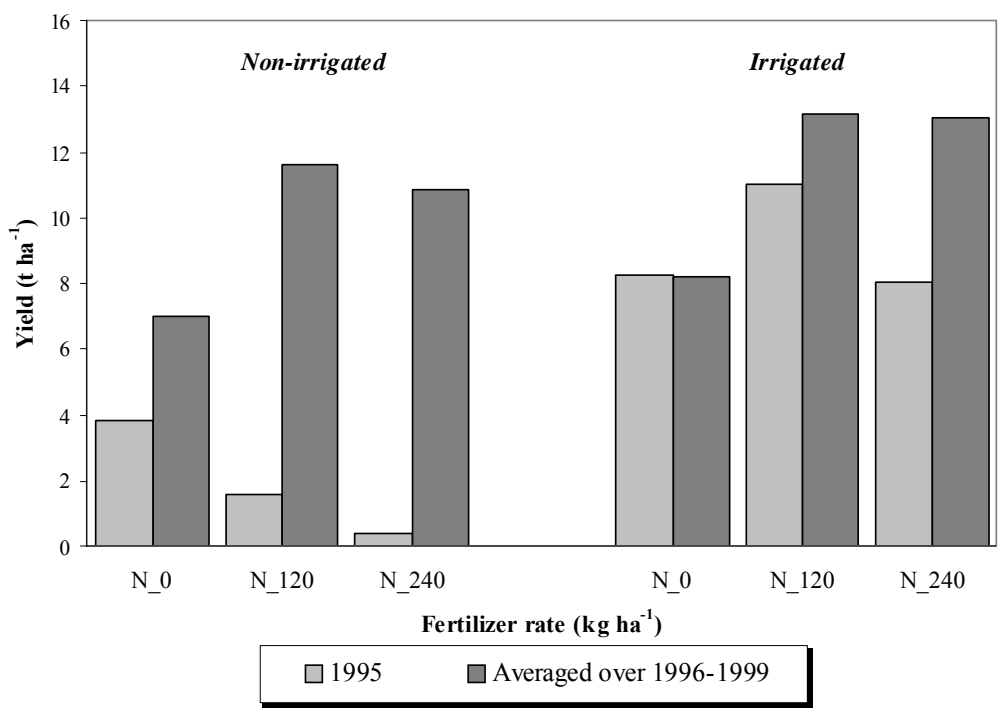


In the period from 1996-1999, which was favorable as regards precipitation for maize, fertilization reliably increased the yield of maize even without irrigation, in the average of four years. The surplus yield of fertilization was 3.9-4.6 t/ha depending on the level fertilizer treatments. The surplus yield reached its maximum on the plot where the lower $120 \mathrm{~kg}$ nitrogen dose was applied. In the case of $240 \mathrm{~kg} \mathrm{~N} / \mathrm{ha}$ application, the yield of maize did not differ from this previous value.

Due to the effect of irrigation, yield was significantly higher at all three nutrient-supply levels compared to the unirrigated treatments. The highest fertilizer dose - just like in unirrigated conditions did not increase the yield of maize considerably. Upon evaluating the correlation of fertilization and irrigation the yield increasing effect of fertilization did not differ in irrigated and unirrigated treatments in a way that could be statistically proven (Table 2). The reliable year or year $\mathrm{x}$ irrigation correlation supports, that yield surplus $(1.3-2.3 \mathrm{t}$ ha-1) significantly differed from the irrigation effect measured in 1995.

\section{CONCLUSION}

When evaluating the results of the experiment, we found that fertilization and year significantly influenced the efficiency of irrigated maize production. In irrigated cultivation, the condition of efficient farming is ensuring appropriate nutrient supply. Our experimental data have justified the results of previous research results according to which, the amount of precipitation or the moisture stored in the soil modifies the fertilizer effect, meaningthat less fertilizer is needed with lower water supply.

According to the results of the experiment, the $240 \mathrm{~kg}$ nitrogen and the related $\mathrm{P}$ and $\mathrm{K}$ application is not recommended in any condition, since compared to the $120 \mathrm{~kg}$ ha- $1 \mathrm{~N}$-dose, it did not increase the yield of maize considerably. In droughty years, it caused a significant yield decrease. This amount of $\mathrm{N}$ fertilizer dose unambiguously results in over-fertilization, it decreases the profitability of maize production significantly and the farms can expect a great loss as a result. Along with this, it also means a constant, potential source of danger since in irrigated cultivation the high dose of $\mathrm{N}$-fertilizer can multiple the amount of nitrate leaching from the root zone, increasing the harm on ground waters. When determining the optimal amount irrigation, we have to consider the amount of appied $\mathrm{N}$-fertilizer as well as the NO3 content of the soil in order to avoid leaching from the upper layer.

\section{ACKNOWLEDGEMENTS}

This research was supported by the Hungarian National Research Fund (OTKA T042749).

\section{REFERENCES}

Balogh, J. (1978): Calculating water needs in irrigated treatments. Mezőgazdasági Kiadó, Budapest

Box, G. E. P.-Wilson, K. B. (1951): On the Experimental Attainment of Optimum Conditions. Journal of the Royal Statistical Society, 13. 1.

Drimba, P.-Ertsey, I. (2003): Evaluation of maize yield in the function of fertilization with regards to risks. Kukorica hibridek adaptációs képességének és termésbiztonságának javítása. Debrecen, 149-163.

Drimba, P.-Ertsey, I.-Petró, Zs. (2000): Risk Programming Models for Planning Plant Production. $17^{\text {th }}$ European Conference on Operational Research, Budapest, 120.

Ertsey, I.-Drimba, P. (1995): A few characteristics of decision support models applicable in agriculture. DATE, Tud. Közl., Debrecen, 53-68.

Huzsvai, L.-Nagy, J. (2003): Effect of nutrient resupplying and irrigation on the yield of maize (Zea mays L.). Civis-Copy Kft., Debrecen, 79-92.

Kovács, G. J. (1982): The critical ecophysical correlation of waterand nutrient dynamics of maize. Növénytermelés, 31. 4. 355365.

Kramer, P. I. (1963): Water stress and plant growth. Agron J. Madison, 55. 31-35.

Megyes, A.-Rátonyi, T.-Nagy, J. (2003): Evaluation of conservation tillage systems in corn production. Civis-Copy Kft., Debrecen, 141-148.

Nagy, J.-Huzsvai, L.-Németh, T.-Megyes, A. (2003): The effect of soil cultivation on the moisture content and nutrient resources of soil. Civis-Copy Kft., Debrecen, 129-140.
Nagy, J. (1994): The effect of fertilization and irrigation on the yield of maize (Zea mays L.) hybrids with varions genotypes. Unipress, Padova, 421-440.

Nagy, J. (1995): Evaluating the effect of fertilization on the yield of maize (Zea mays L.) in different years. Növénytermelés, 44. 5-6. 493-506.

Nagy, J. (1996): Interactions between fertilization and irrigation and plant density of maize (Zea mays L.). Cereal Research Communications, 24. 1. 85-92.

Nagy, J. (1997): The effect of fertilization on the yield of maize (Zea mays L.) in irrigated and unirrigated treatments. Agrokémia és Talajtan, 46. 1-4. 275-288.

Nagy, J. (2000): A talajművelés és a mütrágyázás hatása a kukorica (Zea mays L.) termésére aszályos és kedvező évjáratokban. In: Nagy, J.-Pepó, P. (szerk.) Növény. és talajtudomány a mezőgazdaságban. Vider Plussz, Debrecen, 97-119.

Nagy, J. (2001): The effect precipitation on the yield of maize (Zea mays L.). In: Nagy, J. et al. (ed.) Current soil and environmental science in agriculture. Debrecen, 177-190.

Petrasovits, I. (1978): Main questions of agrohydrology. Akadémiai Kiadó, Budapest

Sváb, J. (1981): Biometrical methods in research. Mezőgazdasági Kiadó, Budapest

Szőke Molnár, L. (1977): Economical questions of irrigated maize production. Kukoricatermelés, Akadémiai Kiadó, Budapest 